\title{
Methods of Measuring the Effectiveness of Logistics Activities
}

\author{
Robert Dmuchowski
}

\begin{abstract}
Companies which wish to operate on the market must constantly discover and shape new potentials and abilities to create benefits that might ensure them long-term increase in efficiency and development. One of the ways to gain economic advantage is to reduce costs in all possible areas of their generation and maximize consumer satisfaction through more efficient and rational flow of primary products and goods (Manzouri \&, Ab Rahman, 2013). Logistics, understood as a modern management concept, allows to achieve such economic and market effects. Comprehensive management of all activities related to material flows, goods or services from supply sources to users of finished products brings benefits in reducing total costs, which results in better economic results. Companies use various sets of indicators for measuring economic and operational efficiency and the most commonly used ones are profitability rates. The main goal of the article is to present an assessment of the efficiency of logistics processes based on the unit costs which arise in the areas recognized as logistic. The research problem is to indicate the method of measurement in order to examine the relationship between logistics management and the reduction of total costs and thus to study the impact of supply chain management on the efficiency and effectiveness of an economic entity. The applied research method is based on calculating the value of logistic cost-effectiveness coefficients and presenting them in dynamic terms. Lower values of the logistic cost-effectiveness coefficients will mean better logistic effects and more rational use of resources. The use of the presented measurement methods will allow company managers to create the most optimal supply chains in their business ventures. The article presents the cost-effectiveness rates calculated for logistics processes in the period 2018-2019 in the Large-area Multi-Branch Materials Warehouse in Kutno (centrally located, modern logistics warehouse) and the Materials Warehouse Jawidz.
\end{abstract}

KEY WORDS: $\quad$ Logistics management, logistics processes, efficiency.

JEL Classification: C61, C83, D24, D61, 012.

University of Computer Sciences and Economics in Olsztyn, Poland

\section{Introduction}

Business conditions for companies are constantly changing, mainly as a result of the impact of globalization processes. Enterprises must introduce various changes to their goals and structures, and they should have the skills to shape the future and development directions (Olkiewicz, 2018). Business

Correspondence concerning this article should be addressed to: Robert Dmuchowski, University of Computer Sciences and Economics in Olsztyn, Poland. E-mail: rdmuchowski@wp.pl adapts to the external environment which imposes restrictions as well as enforces specific actions aimed at rational use of resources. Business entities improve in terms of acquiring customers for their products or services. They implement innovative ideas in the area of creating new products, manufacturing processes and organizational changes that improve the quality and efficiency of production or 
services. All these activities are extremely costly but also necessary for development or survival in the competitive market.

By introducing original and previously unknown changes, management boards of companies seek to gain a leadership position in the areas of costs, prices, quality, new products, new sales systems and contacts with customers. Companies which are looking for ways to increase their profitability will strive to introduce changes that will lead to increasing their attractiveness and profitability. The effectiveness of business operations is something obvious in the modern market and for this reason business strategies will always assume the possibility of achieving greater effects in relation to costs (Atkinson et al., 2008). One of the ways to gain competitive advantage is to reduce costs in all areas of their generation and to maximize consumer satisfaction through a more efficient and rational flow of primary products and goods. Logistics, understood as a modern management concept, constitutes the source of obtaining such economic and market effects (Świerczek, 2019). Comprehensive management of all activities related to material flows, goods or services from supply sources to users of finished products brings benefits in reducing total costs and thus ensures greater efficiency in relation to other business entities, enterprises or processes.

The essence of the logistics management process is to rationalize company's activities in the area of integrated flows of goods and information, in which the set goals are aimed at efficiency by minimizing costs and strategies are oriented on time, flexibility, quality and innovation (Bardi et al., 2002).

The implementation of company's goals depends on the degree of utilization of its potentials. These assets make it possible to conduct business activities, achieve competitive advantage and realize the adopted economic assumptions, which most often manifest themselves in the form of profit and company development. Increasing competition constantly sets new requirements for enterprises in terms of new products, their quality as well as costs and prices. This makes management more and more difficult.

The adopted goals and action strategies allow to treat logistics concepts as determinants of the effectiveness of enterprise management (Petrykowska, 2009). Logistics as a concept of modern management is oriented towards the integration of all logistic functions and processes and allows not only to coordinate effectively all physical flows of goods and services, but also has the ability to solve problems and use the potential of effects in operational and strategic activities of an enterprise (Dmuchowski, 2018). Logistics, due to its importance in a company as well as the roles and tasks it fulfills, must still evolve, discover and shape new potentials and ability to create benefits, thus ensuring the development of a company and its cooperation with other entities, adapting to dynamic changes in the economic environment (Blaik et al., 2013).

A modern economic entity will implement "creative destruction" by creating new value chains that are to ensure faster and better delivery and cheaper products and services. The process of shaping and using logistics in a company involves integrated actions aimed at improving the structure of logistics networks as well as economic and market effects in the whole system of creating and delivering goods. This means that at the center of integrated business management, especially strategic management, there should be systematic processes for improving existing and discovering new logistic possibilities and capabilities aimed at increasing efficiency and competitiveness of a company (Blaik, 1997). The experience and economic results of the best economic entities in the industry show that shaping the functions of processes and logistics instruments in integration aspects in the scale of the entire enterprise management system should be treated in a systemic way. This is reflected in revaluation of logistics assumptions - from an operational approach focused on steering logistics activities towards a system concept of oriented enterprise management, in which logistics would be the basic management criterion.

Active, national and global competition in areas of business activity is changing very dynamically and decisively. Changes in consumer behavior and wide access to information and new technologies trigger the need to develop a new approach to 
the current concept and organization of the supply chain.

Changes taking place in the company's environment are multilateral today, they affect all its spheres and levels of functioning, force a specific transformation and adaption to the structure and potential of this environment. Changes implemented by a company to improve processes, structure, products or innovations are necessary and indispensable to maintain market position. This is connected with incurring higher and higher operating costs and the risk concerning future profits.

Running a business is associated with taking risks and a new venture does not always guarantee expected economic effects. Sometimes it can even bring a loss to a company. Therefore, company managers apply management concepts that will be most optimal for them from their company's point of view. Rationalizing logistics processes can provide a competitive advantage on the market due to the fact that costs of production, goods and services flows as well as inventories are reduced, and the quality of services is improved.

The use of appropriate strategies and concepts for enterprise management is only an introduction to business operations conducted in the global, competitive market. Financial and economic results must be subject to constant control due to the rapidly changing external conditions. The demand for economic information regarding both changes in the environment and processes implemented inside enterprises is growing (Bławat, 2016). A significant part of this information is obtained as a result of an analysis of the effects achieved by an enterprise as well as of the resources it possesses and their use. A designed logistics system in an enterprise or sector, aimed at limiting or even eliminating certain cost groups, must be permanently verified and improved. Continuous and rapid changes on the market in terms of products, prices, quality or even a competition strategy require changes in the concepts of supply chain management. However, it is impossible to create a model of a logistics system and to rationalize it without having proper research tools. There is no doubt that increasing company's operational efficiency by shortening delivery times, reducing inventory, efficient collection and quick access to information contribute to reducing production costs, increasing profitability and, thus, business competitiveness (Luczko et al., 2019).

However, there is still a question concerning methods of quantifying profits as a result of improving those areas of logistics management.

\section{Models and Methods of Measuring the Effectiveness of Logistics Activities}

Efficiency is an important economic category and a significant indicator of any company's performance (Bacs et al., 2018), used to analyse company's operations but also to assess the effectiveness of logistics processes. The success of planned business ventures will depend on efficiency and effectiveness of logistics processes, therefore, the analysis of measuring the effectiveness of logistics activities is so important. Logistics processes management undoubtedly contributes to reducing production or service costs, and thus to increasing profitability of business operations.

Performance measurement is critical to improve the effectiveness and efficiency of a company as well as and the supply chain (Gunter \& Shepherd, 2006). The literature review shows that the most used models for the measurement of logistics performance are the following (Paddeu, 2016):

1. Key Performance Indicators (KPIs) can be defined as a set of indicators used to measure the success of a company through the measurement of the performance of a particular

activity or process. Based on the values of the indicators, a manager can decide which action has to be taken to improve the performance of a specific area. In fact, the determination of priorities of a given set of KPIs is a critical element in improving the management of the supply chain. (Cai et al., 2009). The most important factors related to logistics processes are: quality, timeliness, logistics costs, productivity and capacity. The quality attribute is related to both the quality of the processes and that of the product along the supply chain; it is indispensable to measure the level of customer satisfaction. The timeliness attribute is related to the response time of the supply chain, required to meet the needs of customers. The logistics costs attribute is related to the financial logistics performance, whereas productivity 
and capacity attribute is related to the efficiency of the use of the resources. KPIs can therefore be used to measure the performance of a specific process of the supply chain.

2. Balanced Scorecard (BSC) model is a performance evaluation model based on a balanced approach to financial and non-financial indicators. Traditional performance indicators do not fully reflect the actual performance of a company. Non-financial indicators are as important as financial indicators in analyses of the company's development because they affect customer satisfaction as well as rationalization of internal processes, and thus ensure improvement of the company's effectiveness, innovation of its products and economic processes). These indicators are very important for the competitiveness of a company; in fact, they allow managers to consider all measures of performance and to assess whether it is possible to achieve improvement in a specific area, without affecting the performance of other areas.

3. Business Excellence Model (EFQM) model -it is a quality control tool which ensures the achievement of the intended economic results.

4. Performance Prism model. This model considers the relationships between the different actors involved in the processes within the supply chain. The stakeholders are the core of the model, which considers five different (but interrelated) performance perspectives (Adams et al., 2001): stakeholders' satisfaction, strategies, processes, ability, stakeholder's contribution.

5. Supply Chain Operations Reference (SCOR) model is the most used model within the management supply chain performance assessment. It enables companies to analyze the performance of their supply chain in a systematic way by improving communication between the various members of the chain, while, The model has a hierarchical structure characterized by three levels, for each of which processes (shared into the areas: reliability, responsiveness, flexibility, cost and resources) are defined with a level of detail which increases from level 1 to level 3 . The processes associated with each level are (Paddeu, 2016)

1 ) source, ordering and receiving raw materials and products.

2) make, manufacturing, producing, repairing, modifying or recycling materials and products.
3) deliver, receiving, programming, taking, packing and delivering products that are ordered by customers.

4) return, managing the logistics of returning products and goods not suitable for sale and packaging. at the same time, optimizing the network and the performance of each region and then of the supply chain as a whole.

The method of measuring profits presented in the article will be based on logistic cost-effectiveness factors. Increasing the size of business will increase the overall cost of the project. The research method used will indicate what kind of quantity and structure of unit costs should be focused on (organization of logistic costs) so that the total costs are as low as possible. It has been assumed that if Event A occurs, it will definitely result in effect $B$. The main emphasis should be placed on answering the question what costs should be incurred to cause phenomenon $\mathrm{A}$ in order to obtain the expected effect of size $B$, and this is to be done by searching for appropriate research methods that replace the presumption described above.

Cost-effectiveness rates are a contradiction of the concept of efficiency. It is, however, indisputable that costs are incurred when conducting business activities. A larger scale of production will always be associated with increased tangible and intangible expenditures. Rational and competitive management of an economic entity will be reduced to such undertakings that the ratio of each additional batch of produced goods or services is more favorable in relation to the costs incurred. Therefore, lower values of costeffectiveness ratios, in dynamic terms (concerning a certain period of time) in the areas of cost generation mean higher efficiency in managing resources. The analysis of cost-effectiveness rates is necessary to assess the effectiveness of the existing logistics system in an enterprise and provides information to create a more optimal supply chain.

There is no one universal method that could describe all phenomena and at the same time would be burdened with such a small error that it could be considered fully reliable. Hence, there is a need to isolate and group costs into those with such features for which it is possible to adopt detailed research methods not burdened with defects in universal measures (Dmuchowski, 2011).

There are many types of cost division proposed by 
scientists involved in logistics theory. According to Elżbieta Wolgramm, a representative of the company A.T. Kearney which deals with studies on the impact of logistics on reducing total costs, logistics costs include the costs of: transport, storage, administration and frozen capital (Lichocik, 1998). According to K. Kowalska, the main logistics costs are transport and storage costs (Kowalska, 2009). The structure of the logistics costs of a production company is shown in Figure 1 (Fechner \& Szyszka, 2006). Neither of these divisions can be questioned. Undoubtedly, all incurred costs are important for the company's profitability. However, from the point of view of logistics strategy, the focus is on those costs that have the greatest impact through logistics management. It can therefore be said that there is a group of costs that are neutral in terms of making decisions in the logistics management process.

For the reliability of calculations and the choice of the adopted test method, the selection of the cost groups that make up logistics costs will be determined by the method of collecting data in a specific enterprise.

Therefore, it seems most appropriate to adopt the following distribution of logistics costs:

a) transport costs related to the supply of primary products and distribution of finished

products,

b) costs of storing primary products and finished products,

c) costs of maintaining points of sale,

d) costs of frozen capital,

e) administration costs.

However, it must be remembered that reducing global costs is not an end in itself. It would be a method of achieving high profitability ratios in a short period of time, however, it would bring benefits and harms difficult to determine from the point of view of the company's strategy. Therefore, one should focus on the quantity and structure of unit costs by methods allowing to indicate sources of their origin and their reduction by organizational methods, without losing sight of market goals (Skowronek \& SyrjuszWolski, 1995). Increasing global costs, e.g. increasing expenditures on market research programs, does not always have to increase costs per product, assuming that they fulfill their role, i.e. there is an increase in production. In other words, it is about incurring such expenditures that increase efficiency. A characteristic phenomenon (with an increase in work productivity) is more than proportional increase in sales that accompanies the increase in the unit of expenditure. In the areas of costs considered to be logistic that interest us, it is possible to distinguish the costeffectiveness ratio and indicate areas where logistics methods can be used (Dmuchowski, 2019).

The following formula of the logistic costeffectiveness factor is adopted (own study based on Gabrusewicz, 2002):

$W_{K L O G}=\frac{\sum_{i=1}^{n} M_{L O G} \times C_{L O G}}{\sum_{i=1}^{n} P \times P_{C J}}$

where,

$\mathrm{M}_{\mathrm{LOG}}$-number of expenditure units e.g. (tonnekilometers, $\mathrm{m} 2$ of area),

$\mathrm{C}_{\mathrm{LOG}}$ - unit price e.g. (tonne-kilometers, $\mathrm{m} 2$ ),

$\mathrm{P}$ - number of products, materials,

$\mathrm{P}_{\mathrm{C}}$ - unit price in PLN.

Taking into account the distribution of logistics costs:

$W_{K T}=\frac{\sum_{i=1}^{n} M_{T I} \times C_{T I}}{\sum_{i=1}^{n} P_{J} \times P_{C J}}$

where,

$\mathrm{W}_{\mathrm{KT}}$ - transport intensity rate,

$\mathrm{M}_{\mathrm{TI}}$ - number of tonne-kilometers (tkm)

$\mathrm{C}_{\mathrm{TI}}$ - price $1 \mathrm{tkm}$

$W_{K M}=\frac{\sum_{i=1}^{n} M_{M I} \times C_{M I}}{\sum_{i=1}^{n} P_{J} \times P_{C J}}$

where,

$\mathrm{W}_{\mathrm{KM}}$ - storage cost rate,

$\mathrm{M}_{\mathrm{MI}}$ - number of $\mathrm{m}^{2}$ of warehouse space,

$\mathrm{C}_{\mathrm{MI}}-$ cost of $1 \mathrm{~m}^{2}$ of a warehouse.

$$
W_{K Z}=\frac{\sum_{i=1}^{n} M_{K Z} \times C_{K Z}}{\sum_{i=1}^{n} P_{J} \times P_{C J}}
$$

where,

$\mathrm{W}_{\mathrm{KZ}}$ - capital freeze rate,

$\mathrm{M}_{\mathrm{KZ}}$ - amount of inventory,

$\mathrm{C}_{\mathrm{KZ}}$ - unit price of inventory.

$$
W_{K A}=\frac{\sum_{i=1}^{n} M_{K A} \times C_{K A}}{\sum_{i=1}^{n} P_{J} \times P_{C J}}
$$

where, 
$\mathrm{W}_{\mathrm{KA}}$ - administration rate,

$\mathrm{M}_{\mathrm{KA}}$ - number of employees,

$\mathrm{C}_{\mathrm{KA}}$ - average salary.

The formulas for calculating capital intensity rates may serve for a more detailed study of cost generation. However, with the assumption that the collected data (accounting analytics) will allow for such detailed research, the transport intensity rate may consist of partial factors (Twaróg, 2009, p. 48):

$W_{K T}=W_{C K A}+W_{C K P}+W_{C K M}+W_{C K I N}+W_{C K U F}$ (6)

where,

$\mathrm{W}_{\mathrm{CKA}}$ - rate of depreciation costs involved in logistics processes

$\mathrm{W}_{\mathrm{CKP}}$ - rate of labor costs being the product of employees in logistics processes and average

salary,

$\mathrm{W}_{\mathrm{CKM}}$ - rate of consumption of materials, fuels and energy,

$\mathrm{W}_{\text {CKIN }}$ - rate of other flow costs,

$\mathrm{W}_{\text {CKUF }}$ - rate of external costs.

Similar rules will apply to other remaining costeffectiveness rates: storage $\left(\mathrm{W}_{\mathrm{KM}}\right)$, frozen capital $\left(\mathrm{W}_{\mathrm{KZ}}\right)$, administration $\left(\mathrm{W}_{\mathrm{KA}}\right)$.

The logistic cost ratio will therefore have the formula (Trus, 2010, p. 47):

$W_{K L O G}=W_{K T}+W_{K M}+W_{K A}+W_{K Z}$

Therefore, when developing a company's logistics strategy, it must be remembered that the logistics cost factor in the period after the strategy is introduced should be smaller than the base period factor, that is:

$\mathrm{W}_{\mathrm{KLOG}}{ }^{1}>\mathrm{W}_{\mathrm{KLOG}}{ }^{1+\mathrm{n}}$.

The presented method of measuring logistics efficiency based on cost-effectiveness rate was used to study the efficiency of these processes in the Largearea Multi-Branch Materials Warehouse in Kutno (centrally located, modern logistics warehouse) and the Materials Warehouse Jawidz in the period 2018-2019. These are military warehouses and store supplies for war or crisis. It must be explained why the author of publications uses in his scientific research empirical data of an institution that is not a business economic entity and its main purpose of activity is not to achieve the highest possible profit. Enterprises that are the subject of the author's interest operate on the market, have an extensive logistics system and their competition strategy is based on the concept of logistics management. However, they do not want to share their economic and operational data due to the fact that it might make them vulnerable to the effects of competition. A business enterprise would be a much better model to calculate the current logistics efficiency and design a more rational model of logistics processes, where logistics processes and their areas (that are particularly cost-intensive and their elimination leads to improvement of the company's economic situation and gaining a competitive advantage) could be presented in a full system, from the sources of supply to users of finished products. The best example is the presentation of the rates of cost intensity and inventory maintenance. In financial theory and business practice, high levels of current assets caused by generating excessive liquidity costs have a negative impact on the company's profitability, and their insufficient level may increase the risk of loss of liquidity and, as a consequence, lead to a number of difficulties in maintaining an undisturbed operation of a company (Van Horne \& Wachowicz, 2004). The level of current assets should be optimized in each company (Bieniasz \& Gołaś, 2011). Therefore, supply chains should be constantly adjusted (Carlson et al., 2010). Economic entities shape their logistics processes in such a way that the cost position of "inventories" is lower, they often even apply the strategy of inventory management "just in time", limiting them to the necessary minimum, while guaranteeing production continuity (Shraybfeder, 2005). In contrast to business, the purpose of logistics processes in the army is primarily to maintain an adequate level of stocks in the event of various threats, therefore, it is not possible to calculate profitability because the military does not run a business and does not sell its products. Nevertheless, the presented method of measuring logistics efficiency is possible to apply in case of institutions such as the military, which also must and should be guided by the rationality of 
expenditure and reduce the costs of storage, transport, service, reloading or handling.

The method of measuring logistics efficiency presented in the article can be considered universal, because it can be used both to calculate the efficiency of logistics processes of large corporations as well as SMEs. It can also be expanded and modified, for example, by profitability ratios, where the systematically improved organization of logistic processes should ensure the reduction of logistics costs: $\mathrm{W}_{\mathrm{KLOG}}{ }^{1}>\mathrm{W}_{\mathrm{KLOG}}{ }^{1+1} \mathrm{WKLOG} 1+\mathrm{n}$, and a smaller percentage share of costs in implemented economic effects should ensure an increase in profitability : $\mathrm{R}^{1}$ $<\mathrm{R}^{1+1}<\mathrm{R}^{1+\mathrm{n}}$.

\section{Results}

The data needed to calculate the logistic costeffectiveness rates for the Kutno and Jawidz warehouses is presented in Table 1 .

The application of formulas presented in the article for calculating the logistic cost-effectiveness rates: $\mathrm{W}_{\mathrm{KT}}, \mathrm{W}_{\mathrm{KM}}, \mathrm{W}_{\mathrm{KA}}, \mathrm{W}_{\mathrm{KZ}}$, as well as empirical data on the operation of military storage warehouses in the period 2018-2019 allowed to indicate the areas of emergence of logistic costs related to the reception, storage and distribution of inventory at warehouses in Kutno and Jawidz, which is presented in Table 2.

The calculated total logistics cost-consumption rates: $\mathrm{W}_{\mathrm{KT}}+\mathrm{W}_{\mathrm{KM}}+\mathrm{W}_{\mathrm{KA}}$ (Table 2) are higher in Warehouse in Jawidz ( $\mathrm{W}_{\mathrm{KL} \text { og }}=0,413$ and 0,544), which proves that there is greater expenditure in transport, storage, warehouse maintenance and reloading works for 1 ton of inventory than in Largearea Multi-Branch Materials Warehouse in Kutno $\left(\mathrm{W}_{\mathrm{KL} \text { og }}=0.114\right.$ and 0.226$)$.

A very worrying phenomenon is that the total cost-effectiveness rates of 2019 were higher compared to $2018\left(\mathrm{~W}_{\mathrm{KLOG}}{ }^{2018}=0,413<\quad \mathrm{W}_{\mathrm{KLOG}}{ }^{2019}=\right.$ $0,544)$-Warehouse in Jawidz, $\left(\mathrm{W}_{\mathrm{KLOG}}{ }^{2018}=0,114<\right.$ $\left.\mathrm{W}_{\mathrm{KLOG}}{ }^{2019}=0,266\right)$-Warehouse in Kutno. Therefore, it can be concluded that the logistics organization and the applied potential require improvement and adaptation to implemented logistic undertakings. Deterioration in the area of transport performance is particularly noticeable, where the transport cost rates were as follows: $\mathrm{W}_{\mathrm{Ktr}}^{2018}=0,11, \mathrm{~W}_{\mathrm{Ktr}}^{2019}=0,25$ (Kutno), $\mathrm{W}_{\mathrm{Ktr}}^{2018}=0,39, \mathrm{~W}_{\mathrm{Ktr}}^{2019}=0,53($ Jawidz$)$.
Transport cost rates in the examined period significantly affect the deterioration of the efficiency of logistics processes in both warehouses in Kutno and Jawidz, they also constitute as much as $94-96 \%$ of the total ratio. The vehicles used for transporting goods from warehouses in Kutno and Jawidz are the companies' own vehicles with a capacity of 10-15 tons, performing transport to other warehouses at a distance of 150 to $450 \mathrm{~km}$. The main factor behind the generation of high transport costs is the unit operating cost index of PLN 15.59-15.79 per $1 \mathrm{~km}$, with the national average price PLN 3.5 per $1 \mathrm{~km}$ (Tkowalski, 2019). The basic selection criterion when testing the transport intensity rate will be the answer to the following question - buy a transport service, or incur costs for own transport? Assuming that a given business, institution uses both its own transport with unit costs - $\mathrm{K}_{\mathrm{TW}}$ and buys transport services on the market $-\mathrm{K}_{\mathrm{TO}}$, then the unit price of transport is:

$\mathrm{C}_{\mathrm{T}}=\frac{\sum_{i=1}^{n} K \mathrm{TW}_{\mathrm{x}} \mathrm{C}_{\mathrm{TO}}}{\sum_{i=1}^{n} \mathrm{M}_{\mathrm{T}}}$

then, $\mathrm{C}_{\mathrm{TW}}=\frac{\mathrm{K}_{\mathrm{TW}}}{\mathrm{M}_{\mathrm{Tw}}}, \mathrm{C}_{\mathrm{TO}}=\frac{\mathrm{K}_{\mathrm{To}}}{\mathrm{M}_{\mathrm{To}}}$, where:

$\mathrm{C}_{\mathrm{T}}$ - price of transport,

$\mathrm{C}_{\mathrm{TW}}$ - price of own transport,

$\mathrm{C}_{\mathrm{TO}}$-price of outsourcing transport,

$\mathrm{K}_{\mathrm{TW}}$ - cost of own transport,

$\mathrm{K}_{\mathrm{TO}}$ - cost of outsourcing transport,

$\mathrm{M}_{\mathrm{TW}}$ - transport work with own transport,

$\mathrm{M}_{\mathrm{TO}}$ - transport work without sourced transport.

With CTW $\geq$ CTO, the choice will be the service offered on the market, however CTW $\leq$ CTO means that it is profitable to maintain one's own transport. The algorithm for proceeding when choosing a transport service (own or outsourced) is shown in Figure 2, which presents a layout of cost relations as an initial process of making strategic decisions.

In the first stage, an entrepreneur determines the costs of transporting goods using own and outsourced transport. In case where the price of outsourced transport is lower than the price of own transport (CTO <CTW) while improving or at least maintaining the quality of services, the 


\section{Table 1}

Financial Data of Kutno and Jawidz Storage Warehouses in 2018-2019

\begin{tabular}{|c|c|c|c|c|}
\hline \multirow{2}{*}{$\begin{array}{l}\text { Business } \\
\text { elements }\end{array}$} & \multicolumn{2}{|c|}{ Kutno } & \multicolumn{2}{|c|}{ Jawidz } \\
\hline & 2018 & 2019 & 2018 & 2019 \\
\hline $\begin{array}{l}\text { Total operating costs, } \\
\text { incl.: }\end{array}$ & PLN 2319171 & PLN 2845451 & PLN 6156372 & PLN 6893501 \\
\hline Transport costs & PLN 107571 & PLN 294651 & PLN 3382218 & PLN 4372251 \\
\hline Storage costs & PLN 1844400 & PLN 1953000 & PLN 2039754 & PLN 1642850 \\
\hline $\begin{array}{l}\text { Total storage space in } \\
\mathrm{w} \mathrm{m} \mathrm{m}^{2}\end{array}$ & 6073 & 6073 & 17699 & 17699 \\
\hline $\begin{array}{l}\text { Storage area for tested } \\
\text { stocks }\end{array}$ & 2100 & 2100 & 17199 & 17199 \\
\hline Administration costs & PLN 367200 & PLN 597800 & PLN 734400 & PLN 878400 \\
\hline $\begin{array}{l}\text { Number of employees } \\
\text { in logistics processes }\end{array}$ & 13 & 14 & 24 & 24 \\
\hline $\begin{array}{l}\text { Average monthly } \\
\text { salary }\end{array}$ & PLN 2550 & PLN 3050 & PLN 2550 & PLN 3050 \\
\hline $\begin{array}{l}\text { Average number of } \\
\text { stocks }\end{array}$ & $1199 t$ & $2432 t$ & $1764 \mathrm{t}$ & $1638 \mathrm{t}$ \\
\hline Value of 1-ton stocks & PLN 64302 & PLN 65493 & PLN 70040 & PLN 72421 \\
\hline $\begin{array}{l}\text { Number of assort- } \\
\text { ments }\end{array}$ & 217 & 183 & 365 & 371 \\
\hline $\begin{array}{l}\text { Costs for carrying out } \\
\text { transport work }\end{array}$ & 1,05 PLN/tkm & 0,90 PLN/tkm & 0,13 PLN/tkm & 0,14 PLN/tkm \\
\hline $\begin{array}{l}\text { Average price paid for } \\
\text { transport services }\end{array}$ & 15,59 PLN/tkm & 15,59 PLN/tkm & $15,79 \mathrm{PLN} / \mathrm{tkm}$ & 15,79 PLN/tkm \\
\hline $\begin{array}{l}\text { Amount of transport } \\
\text { work completed }\end{array}$ & $6900 \mathrm{~km}$ & $18900 \mathrm{~km}$ & $214200 \mathrm{~km}$ & $276900 \mathrm{~km}$ \\
\hline $\begin{array}{l}\text { Quantity of transferred } \\
\text { stocks }\end{array}$ & $465 \mathrm{t}$ & $1090 \mathrm{t}$ & $1705 \mathrm{t}$ & $2412 t$ \\
\hline
\end{tabular}

Note: Own study based on data from the Armed Forces Support Inspectorate.

\section{Table 2}

Logistic Cost-consumption Rates WMWS Kutno and SM Jawidz in the Period 2018-2019

\begin{tabular}{lcccc}
\hline \multirow{2}{*}{$\begin{array}{l}\text { Business } \\
\text { elements }\end{array}$} & $\mathbf{2 0 1 8}$ Kutno & $\mathbf{2 0 1 8}$ & Jawidz \\
\cline { 2 - 5 } Transport cost rates & 0,11 & $\mathbf{2 0 1 9}$ & 0,39 & 0,53 \\
Warehouse cost rates & 0,021 & 0,25 & 0,017 & 0,009 \\
Capital freeze rates & 2,5 & 0,009 & 1,03 & 0,68 \\
Administrative cost rates & 0,013 & 2,2 & 0,006 & 0,005 \\
Total logistics cost- & 0,144 & 0,007 & 0,413 & 0,544 \\
consumption rates & 0,266 & & \\
$\mathrm{~W}_{\mathrm{KT}}+\mathrm{W}_{\mathrm{KM}}+\mathrm{W}_{\mathrm{KA}}$ & & &
\end{tabular}




\section{Figure 1}

Division of Logistics Costs in the Enterprise

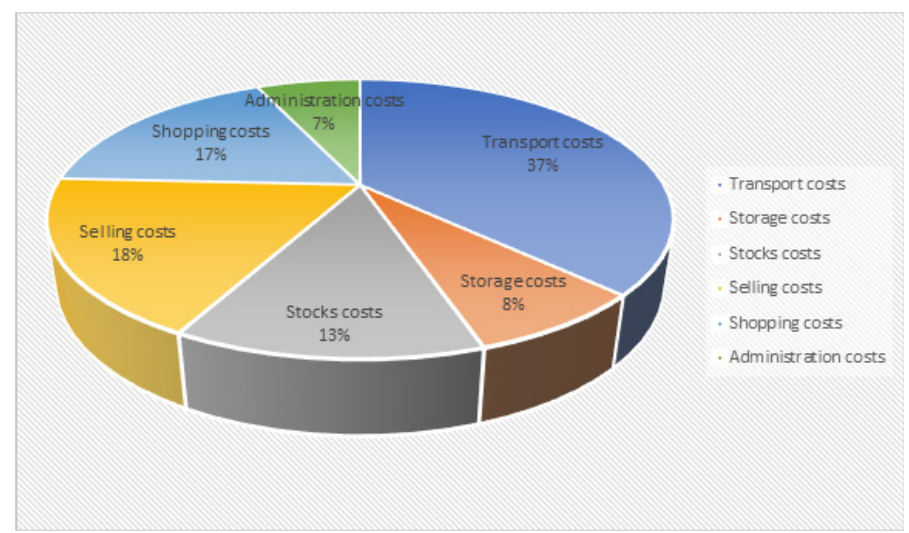

Note: Own study based on data from Fechner, J. \& Szyszka, G. (2006). Logistyka w Polsce [Logistics in Poland]. Biblioteka Logistyczna.

\section{Figure 2}

Stages of Decision Making when Choosing a Variant (Make or Buy) of a Logistics Service

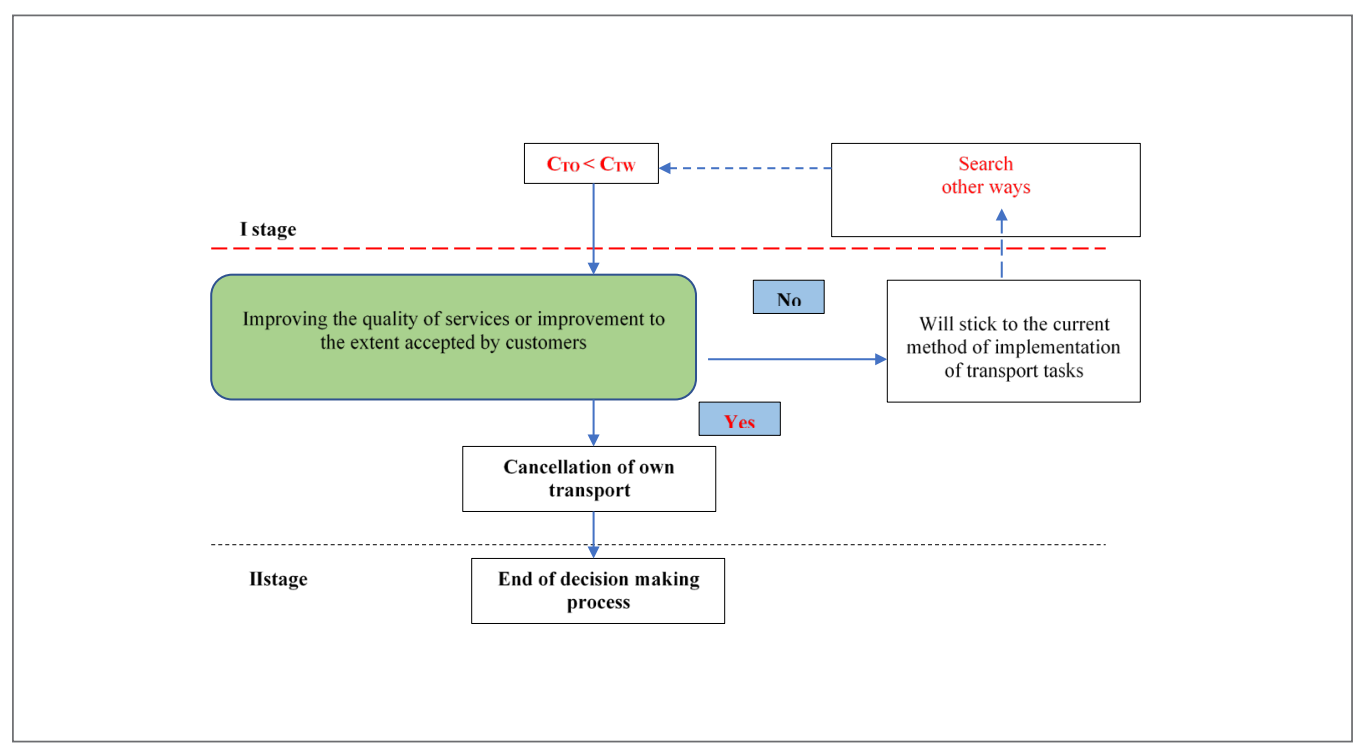


entrepreneur resigns from using own transport (YES for outsourced transport). At the same time, at this stage he starts activities that will allow to reduce the costs of own transport and thus the price of the transport service (NO for the currently used prices of own transport).

Stage II completes the decision-making process. In case where the entrepreneur manages to reduce the costs affecting the price of the service to at least the level of costs offered by competition, he uses own transport. Otherwise, outsourced transport is used.

Warehouse and administration cost rates are decreasing:

$$
\begin{aligned}
& \mathrm{W}_{\mathrm{KM}}{ }^{2018}=0,021>\mathrm{W}_{\mathrm{KM}}{ }^{2019}=0,009(\text { Kutno), } \\
& \mathrm{W}_{\mathrm{KM}}{ }^{2018}=0,017>\mathrm{W}_{\mathrm{KM}}{ }^{2019}=0,009(\text { Jawidz), } \\
& \mathrm{W}_{\mathrm{KA}}{ }^{2018}=0,013>\mathrm{W}_{\mathrm{KA}}{ }^{2019}=0,007 \text { (Kutno), } \\
& \mathrm{W}_{\mathrm{KA}}{ }^{2018}=0,006>\mathrm{W}_{\mathrm{KA}}{ }^{2019}=0,005 \text { (Jawidz), }
\end{aligned}
$$

which proves proper organization and management of logistics processes.

The calculated capital freeze rates $\left(\mathrm{W}_{\mathrm{KZ}}{ }^{2018}=2,5\right.$, $\left.\mathrm{W}_{\mathrm{KZ}}{ }^{2019}=2,2.2\right)$-warehouse Kutno, $\left(\mathrm{W}_{\mathrm{KZ}}{ }^{2018}=1,03\right.$, $\left.\mathrm{W}_{\mathrm{KZ}}{ }^{2019}=0,68\right)$-warehouse Jawidz deserve attention and comment. Each enterprise which operates on a competitive market, where the main goal is to achieve the highest profitability of operations, will strive to reduce the amount of stored inventory to a minimum, which can guarantee undisrupted production activity. Frozen capital rates should be close to the value of other cost-effectiveness rates. The analysis of optimization of logistics processes in warehouses Kutno and Jawidz l ( $\left.\mathrm{W}_{\mathrm{KLog}}{ }^{2018}, \mathrm{~W}_{\mathrm{KLog}}{ }^{2019}\right)$ did not include $\mathrm{W}_{\mathrm{KZ}}{ }^{2018}, \mathrm{~W}_{\mathrm{KZ}}{ }^{2019}$, as this could lead to erroneous conclusions. The advantage of operating military warehouses is that stock can be stored there as long as possible in contrast to business institutions.

The calculated logistics cost rates for warehouses in Kutno and Jawidz confirmed the validity of the theory concerning the creation of large, automated central warehouses. Their central location allows to reduce transport costs, both the costs associated with "filling" warehouses for long-term storage of inventories, as well as their subsequent distribution, where delivery distances are significantly shortened and thus less work is done. Modern warehouses allow goods to be stored for much longer, without having to rotate them constantly, as the right storage conditions are provided. Moreover, automation and computerization of logistics processes allows to reduce the costs of storage, servicing and manipulation of inventories, hence the cost rates of warehouse and administration for Jawidz was higher, compared to warehouse in Kutno.

\section{Conclusions}

Conducting any business requires measuring its effectiveness and it is a necessary procedure that allows a rational allocation of available resources. High efficiency of activities is a good reason for their further intensification, while low efficiency is a warning signal indicating their limitation or even cessation.

The concept of logistics process management allows a company to achieve economic and market effects due to the fact that it deals in a comprehensive way with all related activities of material flows, goods and services, from supply sources to users of finished products - it brings benefits in reducing total costs, and thus, it ensures greater efficiency in relation to other business entities, projects or processes.

The effectiveness of logistics activities can be assessed by means of rates and indicators presented in the article, taking into account the processes of flow phases (supply, production, distribution) and logistics functions (transport, storage, efficiency of workers employed in logistics, coordination of demand).

The research confirms the thesis that logistic management concepts can be considered as the potential for efficiency in reducing costs and increasing productivity, and what is more importantly for the purpose of this article, they prove the presented method of measuring logistics efficiency as a real concept of searching for cost-intensive logistics areas of companies.

The basis for the creation of the universal model is the adoption of the main role of costsin the conducted analysis. A significant part of the logistics costs is fixed costs, the reduction of which can be achieved by improving logistics processes, accelerating the flow of material goods and increasing the inventory rotation speed.

The article not only proved the accepted thesis but also demonstrated that the presented research methods can be successfully used for non-business institutions such as military warehouses in which reserve supplies 
are stored. Despite the fact that such warehouses are not assessed in terms of the amount of goods sold or profits made and do not have to compete with other economic entities, they are required to manage their potential and resources in the most effective way possible. Better economic results (lower operating costs) can be achieved by optimizing logistics processes (transport, warehouse maintenance, better utilization of the logistics potential) without the need to rationalize the level of inventory maintenance (for military institutions this is the primary goal of their activity).

The article is an introduction to the continuation of scientific research in the field of business cluster efficiency. A significant part of logistics costs are fixed costs and the reduction of their unit costs can be achieved by improving logistics processes, accelerating the flow of material goods, increasing the speed of inventory rotation as well as optimal use of the possessed potential. With the use of the methods for measuring the effectiveness of logistics activities presented in the article, the author intends to present research that will show the impact of optimizing logistics costs on the profitability of companies which operate in a business cluster.

\section{References}

Adams, C., Crowe, P., \& Neely, A. (2001). The performance prism in practice. Journal of Measuring Business Excellence, 5(2), 6 -13. https://doi. org/10.1108/13683040110385142

Atkinson, S., Cohn, A., Ducci, M. E., Fernándes, L., \& Smyth, F. (2008). Promotion and prevention within a decentralized framework: Changing health care in Brazil and Chile. The International Journal of Health Planning and Management, 23(2), 153-171. https://doi.org/10.1002/hpm.919

Bacs, Z., Fenyves, V., Karnai, L., Nagy, A., \& Tarnoczi, T. (2018). Financial performance measurement of Hungarian retail food companies. Contemporary Economics, 12(4), 459-472. https://doi. org/10.5709/ce.1897-9254.290

Bardi, J., Coyle, B., \& Langley, J. (2002). Zarządzanie logistyczne [Logistics Management]. PWE.

Blaik, P. (1997). Logistyka jako koncepcja zintegrowanego zarzadzania przedsiębiorstwem [Logistics as a concept of integrated business management]. PWE.

Blaik, P., Bruska, A., \& Matwiejczuk, R. (2013). Logistyka $w$ systemie zarządzania przedsiębiorstwem
[Logistics in the enterprise management system]. PWE.

Bieniasz, A., \& Gołaś, Z. (2011). The influence of working capital management on the food industry enterprises profitability. Contemporary Economics, 5(4), 68-81.

Bławat, F. (2016). Podstawy analizy ekonomicznej: teorie, przykłady, zadania [Basics of economic analysis: theories, examples, tasks]. CeDeWu.

Cai, J., Liu, J.,Liu, X., \& Xiao, Z. L. (2009). Improving supply chain performance management: A systematic approach to analyzing iterative KPI accomplishment. Decision Support Systems, 46(2), 512-521. https://doi.org/10.1016/j. dss.2008.09.004

Carlson, J. P., Franca, R. B., Jones, E. C., \& Richards, C. N. (2010). Multi-objective stochastic supply chain modeling to evaluate tradeoffs between profit and quality. International Journal of ProductionEconomics,127(2), 292-299. https://doi. org/10.1016/j.ijpe.2009.09.005

Dmuchowski, R. (2011). Metody badan analitycznych jako część strategii procesu zarządzania logistycznego [Analytical research methods as part of the strategy of the logistics management process]. Roczniki Naukowe WSIE TWP, Seria B, Nauki Ekonomiczne i Informatyka, 4(1), 175-187.

Dmuchowski, R. (2018). Zarządzanie logistyczne jako strategiczny potencjał przedsiębiorstwa [Logistic management as a strategic potential of the enterprise]. Warmińsko-Mazurski Kwartalnik Naukowy, 3-4(27-28), 99-108.

Dmuchowski, R. (2019). Strategic decisions in supply chains. Collective Monograph: Strategies for Sustainable Socio-Economic Development and Mechanisms their Implementation in the Global Dimension, 3, 33-45. https://doi.org/10.1016/j. jpolmod.2018.01.003

Szyszka, G. (2006). Logistyka w Polsce [Logistics in Poland]. Biblioteka Logistyka.

Gabrusewicz, W. (2002). Rachunkowość zarządcza [Managerial accounting]. PWE.

Gunter, H., \& Shepherd, C. (2006). Measuring supply chain performance: current research and future directions. International Journal of Productivity and Performance Management, 55(3/4), 242-258. https://doi.org/10.1007/978-3-642-13382-4_6

Kowalska, K. (2009). Analiza całkowitych kosztów procesów logistycznych [Analysis of the total costs in logistics processes]. In Logistyka, 2. Instytut Logistyki i Magazynowania.

Lichocik, G. (1998). Rola logistyki w przedsiębior- 
stwie [The role of logistics in the enterprise]. Rzeczpospolita, (3), 8-12.

Luczko, M. R., Lukanovska, I. R., \& Ratynskyi, V. (2019). Modelling inventory management, Separate issues for construction and application. International Journal of Production Management and Engineering, 7(2), 117-124. https://doi. org/10.4995/ijpme.2019.11435

Manzouri, M., \&Ab Rahman, M. N. (2013). Adaptation of theories of supply chain management to the lean supply chain management. International Journal of Logistics Systems and Management, 14(1), 38-53. https://doi.org/10.1504/ IJLSM.2013.051019

Olkiewicz, M. (2018). Quality improvement through foresight methodology as a direction to increase the effectiveness of an organization. Contemporary Economics, 12(1), 69-80. https://doi. org/10.5709/ce.1897-9254.264

Paddeu, D. (2016). How do you evaluate logistics and supply chain performance? A review of the main methods and indicators. European Transport, 61(4), 1-16.

Petrykowska, J. (2009). Funkcje logistyczne w procesie obsługi klienta [Logistics functions in the customer service process]. Acta Universitatis Nicolai Copernici. Ekonomia (40), 19-28. https:// doi.org/10.12775/AUNC_ECON.2009.002

Shraybfeder, D. (2005). Efficient inventory control. Alpina Business Books.

Skowronek, Cz., \& Sarjusz-Wolski, Z. (1995). Logistyka w przedsiębiorstwie [Logistics in enterprises]. PWE.

Świerczek, A. (2019). Zarządzanie łańcuchem dostaw [Supply chain management]. PWE.

Van Horne, J. C., \& Wachowicz, J. M. (2004). Fundamentals of financial management (12 ed.). Prentice-Hall, Inc.

Kowalski, M. (2019). Truck transport - price list for 1 kilometer. https://www.transport-com. $\mathrm{pl} /$ ?transport=cennik-przewozowy Retrieved September 2, 2020.

Trus, T. (2010). Logistyka ekonomii [Logistics economics]. PWE.

Twaróg, J. (2009). Koszty logistyki przedsiębiorstw [Enterprise logistics costs]. Biblioteka Logistyczna. 